CZU 343.3/.97

https://doi.org/10.52507/2345-1106.2021-1.06

MODELE NORMATIVE DE INCRIMINARE A INFRACȚIUNII DE FALSIFICAREA PROBELOR ÎN LEGISLAȚIA DIFERITELOR STATE

PITERSCHI Eugeniu,

Șef al Direcției evaluare operațională și control organizațional, doctorand la Academia „Ștefan cel Mare” a Ministerului Afacerilor Interne al Republicii Moldova 


\title{
REZUMAT
}

Infracțiunile contra justiției instituite în Codul penal al Republicii Moldova, sunt grupul faptelor socialmente periculoase, care își aduc urmările negative în cadrul proceselor judiciare. Una dintre acestea, este și acțiunea ilegală de falsificarea probelor, dislocată în 2 variante-tipice normative la art.310 din Legea penală a Republicii Moldova.

Totuși, necitând la faptul că art.310 din Codul penal al Republicii Moldova atrage la răspundere penală subiectul nominalizat direct în modalitatea normativă, acesta din urmă este instituit succint și permite unor acțiuni ilicite din categoria falsului de probe să fie nepedepsite. În acest sens, propunem ca deziderat realizarea unor studii comparative și inițierea unei propuneri de rigoare, în vederea ajustării cadrului normativ autohton în co-raport cu faptele socialmente periculoase săvârşite în realitatea obiectivă.

Cuvinte-cheie: falsificarea probelor, răspundere penală, elemente sancționatorii, drept comparat, Legea penală.

\section{NORMATIVE MODELS FOR CRIMINALIZING THE CRIME OF FALSIFYING EVIDENCE IN THE LEGISLATION OF DIFFERENT STATES}

\author{
PITERSCHI Eugeniu, \\ Head of the Operational Evaluation and Organizational Control Department, \\ $\mathrm{PhD}$ student at the Academy „SStefan cel Mare” of the Ministry of Internal Affairs of the Republic of Moldova
}

\section{SUMMARY}

Crimes against justice established in the Criminal Code of the Republic of Moldova are the group of socially dangerous facts, which have negative consequences in court proceedings. One of these is the illegal action of falsifying the evidence, dislocated in two typical normative variants at art.310 of the Criminal Law of the Republic of Moldova.

However, notwithstanding the fact that art.310 of the Criminal Code of the Republic of Moldova criminalizes the subject directly nominated in the normative manner, the latter is instituted succinctly and allows illegal actions in the category of false evidence to go unpunished. In this sense, we propose as a desideratum the realization of some comparative studies and the initiation of a rigorous proposal, in order to adjust the local normative framework in corelation with the socially dangerous facts committed in the objective reality.

Key words: falsification of evidence, criminal liability, sanctioning elements, comparative law, Criminal Law.

Introducere. Falsificarea probelor reprezintă una dintre infracțiunile care atentează direct la autenticitatea probelor într-un proces civil și/sau penal - în corespundere cu prevederile actuale ale Legii penale a Republicii Moldova.

În condițiile în care Codul penal al Republicii Moldova, la momentul de față prevede expres doar două variante-tipice a modalităţilor normative de săvârșire a infracțiunii de falsificarea probelor, apare necesitatea stringentă de realizare a unor studii multiaspectuale care ar contribui la ajustarea cadrului normativ autohton. Una dintre principalele metode de realizare a acestui deziderat - o reprezintă cercetarea elementelor comparative. Bunele practici din alte state, formează un ansamblu de idei și repere, care-şi aduce cu ușurință aportul la armonizarea legislației naţionale.

În ordinea textuală care urmează a fi relatată în conținutul prezentei analize de cercetare comparativă, ne propunem ca obiectiv, analiza unor variante-tipice a infracțiunii de falsificarea probelor din alte state, care vor contribui esențial pe finalul cercetării, la formularea propunerilor inițiative de completare a Codului penal al Republicii Moldova la compartimentul incriminării formelor și acțiunilor de falsificarea probelor care pot fi săvârșite în realitatea obiectivă.

Gradul de investigare a problemei la momentul actual, scopul cercetării. Momentul esențial și culminant pentru care a fost supus actualmente analizei și studieri tematicei din prezentul demers științific, constă în necesitatea de a evidenția, remarca și plasa pe primplan în viziunea cititorilor a modalităților normative de incriminare a infracțiunii de falsificarea probelor în Legile penale ale altor state. Uneori, se obișnuiește cu principiul de realizarea a demersurilor științifice doar cu operarea trimiterilor doctrinare, considerent din care, în prezenta lucrare intenționăm să specificăm nuanțe novatorii în vigoare, la aspectul dislocării infracțiunii de falsificarea probelor în afara spațiului teritorialadministrativ al Republicii Moldova.

Unul din scopurile de primă-valoarea a respectivului articol științific, îl reprezintă informarea și prezentarea în fața publicului larg, atât a cititorilor cât și a cercetătorilor științifici, a variantelor-tipice legislative ale faptelor antisociale care atentează la autenticitatea probelor întrun proces judiciar (civil și penal) comise pe teritoriul altor state..

Materiale utilizate și metode aplicate. Materialele utilizate la structurarea și asamblarea științifică a articolului cu titlul Modele normative de incriminare a infracțiunii de falsificarea probelor in legislația diferitelor state, o reprezintă punctul titulativ al Legii penale a Republicii Moldova. Totodată, într-un mod prioritar s-a acordat o atenție sporită și Legilor penale ale altor state care conțin elemente esențiale și formează obiectul de bază a prezentului studiu, precum ar fi Codul penal al Republicii Turcia, Republicii Portugalia, Codul 
penal al Regatului Unit al Marii Britanii și Irlandei de Nord, etc.

Metodele știinţifice aplicate în procesul studiului și elaborării prezentului demers științific fac parte din categoria celor mai diverse, fiind utilizate metodele cele mai eficiente în materia cercetării juridice. Astfel, în prim-plan s-a acordat o prioritate metodei analizei și celei comparative. Ulterior, în vederea prezentării unei structuri și esențe cuprinzătoare a articolului, au fost efectuată apelări științifice la metodele sintezei și deducției, inclusiv metoda istorică și metoda empirică.

Rezultatele obținute și discuții. La art.310 C. penal al R. Moldova este prevăzută răspunderea penală pentru două variante-tipice care implică acțiuni ilicite de falsificarea probelor:

a) falsificarea probelor în procesul civil de către un participant la proces sau de către reprezentantul acestuia - art.310 alin.(1) C. penal. Pedeapsa pentru o asemenea faptă poate fi: amendă în mărime de la 850 la 1150 unităţi convenționale sau cu muncă neremunerată în folosul comunității de la 180 până la 240 de ore în ambele cazuri cu (sau fără) privarea de dreptul de a ocupa anumite funcții sau de a exercita o anumită activitate pe un termen de la 2 la 5 ani.

b) falsificarea probelor în procesul penal de către persoana care efectuează urmărirea penală, procuror sau de către apărătorul admis în procesul penal - art.310 alin.(2) C. penal. O asemenea faptă se pedepsește cu: amendă în mărime de la 850 la 1350 unităţi convenţionale sau cu închisoare de până la 3 ani, în ambele cazuri cu privarea de dreptul de a ocupa anumite funcții sau de a exercita o anumită activitate pe un termen de la 2 până la 5 ani [1, art.310].

Infracțiunea de falsificarea probelor cunoaște o poziţie normativă de incriminare detaliată și în Legea penală a Republicii Turcia.

Astfel, în Codul penal al Republicii Turcia, infracțiunea supusă analizei se regăsește în limitele normative ale capitolului IV cu titulatura Infracțiuni impotriva națiunii și a statului din cadrul părții a 2-a cu denumirea marginală Infracțiuni împotriva organelor judiciare sau a Curții de înfăptuire a justiției.

Articolul 271 al Legii penale a Republicii Turcia intitulat Fabricarea unei jigniri, sancționează cu o pedeapsă sub forma închisorii pe o durată de până la trei ani, orice persoană care fabrică unele probe în legătură cu comiterea unei infracţiunii, despre care cunoaște cu siguranță că infracțiunea respectivă nu a fost săvârşită în realitatea obiectivă [2, art.271].

Notabil este faptul că, pe lângă mențiunile precitate și

${ }^{1}$ Marea Adunare Națională a Turciei, numit de obicei doar Meclis (,Parlamentul”), este parlamentul unicameral al Republicii Turci. Constituția Turciei stabilește că Meclisul este singurul corp legislativ al țării. Marea Adunare Națională a fost fondată în Ankara pe 23 forma specificată mai sus privind sancționarea juridică a modalității normative de săvârșire a infracțiuni de falsificarea probelor, legiuitorul turc ${ }^{1}$ la norma statistică 281 a dislocat expres unele forme diferențiate de cea prenotată referitor la aplicarea răspunderii penale pentru comiterea în realitatea obiectivă a infracțiuni de falsificarea probelor.

Prin urmare, în limitele condiționalităților art.281 din Codul penal al Republicii Turcia, cu denumirea generică Distrugerea, disimularea sau modificarea dovezilor, sunt pasibile de răspunderea juridică următoarele acțiuni ilicite ce înglobează în sine fapta de falsificarea probelor:

- distrugerea, ștergerea, alterarea și/sau ascunderea probelor unei infracțiuni cu scopul de a împiedica organelor competente la stabilirea adevărului obiectiv. O asemenea faptă se pedepsește cu închisoarea de la șase luni până la cinci ani, potrivit art.281 alin.(1) Cod penal al Republicii Turcia;

- funcționarul public care distruge, șterge, alterează și/sau ascunde probele unei infracțiuni cu scopul de a împiedica organelor competente la stabilirea adevărului obiectiv - la fel va fi pasibil răspunderii penale. Pedeapsa pentru a asemenea acțiune ilegală va fi una de tipul închisorii, care nu va depăşi termenul maxim de nouă ani de zile calendaristici, în corespundere cu prevederile art.281 alin.(2) Cod penal al Republicii Turcia;

- prezentarea dovezilor false în cadrul unui proces judiciar de către persoana care este subiectul de drept al faptei, înainte ca organele competente să se expună asupra procesului de examinare a materialelor probatorii administrate la caz - constituie la fel o infracțiune din categoria celor de falsificarea probelor. O faptă de genul dat, se va sancționa cu o pedeapsă de tipul închisorii cu reducerea sumei de patru cincimi din minimul pedepsei specificate la art.281 alin.(1) Cod penal al Republicii Turcia, în conformitate cu cerințele normative ale art.281 alin.(3) din Codul penal al Republicii Turcia [2, art.281].

Un alt sistem supus analizei al modalității normative de incriminare a faptei antisociale referitor la falsificarea probelor, îl reprezintă cel instituit de Parlamentul Republicii Italiene.

În corespunderea capitolului I cu denumirea marginală Infracțiuni impotriva activității judiciare din limitele legislative ale titlului III intitulat Dintre crimele impotriva administrării justiției, sunt sancționate penal, complexul formelor și modalităților de săvârşire a infracțiuni de falsificarea probelor.

Articolul $374 \mathrm{cu}$ titlul Fraude procedurale din Codul penal al Republicii Italiene, prevede expres că, oricine, în cursul unei proceduri civile sau administrative, pentru a-

aprilie 1920, în timpul Războiului de Independență. Parlamentul a jucat un rol fundamental în eforturile lui Mustafa Kemal Atatürk pentru fondarea unui nou stat pe ruinele Imperiului Otoman, la sfârşitul Primului Război Mondial. 
1 înșela pe judecător într-un act de inspecție sau experiment judiciar ori expertul în realizarea raportului de expertiză, schimbă artificial starea lucrurilor sau a persoanelor, este pedepsit cu închisoare de la unu la cinci ani - art.374 alin.(1) Cod penal al Republicii Italiene.

Totodată, dacă făptuitorul modifică careva date în cadrul unui proceduri penale care se examinează în ordinea Codului de procedură penală de către o instanță națională sau în fața Curții penale internaționale - la fel constituie o infracțiune din categoria celor de falsificarea probelor. Pedeapsa pentru aceste fărădelegi este una de tipul închisorii pe un termen de la un an până la cinci ani, în condiționalităţile art.374 alin.(2) Cod penal al Republicii Italiene [3, art.374].

Așadar, urmare a mențiunilor normative prenotate în conținutul respectivului demers ştiințific, este important de notat că, legiuitorul moldav, în limitele incriminărilor sale aferent infracțiuni de falsificarea probelor, a dislocat expres două variante-tipice, una care se referă la procesul civil şi cealaltă la procesul penal. Totodată, acțiunea și forma de realizare a laturii obiective a infracțiunii supuse cercetări, o formează expres - falsificarea probelor, care face referire la ambele procese de judecată (civil și/sau penal).

Într-o ordine ştiinţifică comparată cu Legea penală a Republicii Turcia, este de menționat că, la art.271 Cod penal al Republicii Turcia, este instituită elocvent forma normativă de „fabricarea probelor” ca acțiune antisocială care face parte din categoria infracțiuni de falsificarea probelor.

Totodată, notabil este și faptul că, legiuitorul turc nu s-a limitat doar la forma de comitere a infracţiuni de falsificarea probelor prin acțiunea de fabricarea acestora. Astfel, în modalitatea normativă a art.281 Cod penal al Republicii Turcia, se regăsește și alte forme ilicite de săvârşire a infracțiuni de falsificarea probelor. Acestea la rândul lor, se pot manifesta prin acțiunile antisociale de distrugere, ștergere, alterare și/sau ascundere a probelor veridice cu ulterioara prezentare a dovezilor falsificare.

Consecvent cu aceasta, este de notat că, în corespundere cu prevederile art.281 alin.(2) din Codul penal al Republicii Turcia, este pasibil răspunderi penale și funcționarul public care comite infracțiunea de falsificarea probelor.

În continuitatea cercetării, nu putem trece cu vederea aferent incriminărilor legislative din Republica Italia la capitolul sancționării infracțiuni de falsificarea probelor.

Parlamentul Republicii Italiene, a prevăzut expres specificarea că, subiectul de drept care realizează acțiunile ilegale de modificare a datelor și/sau schimbarea artificială a stării lucrurilor ori a persoanelor, va fi pasibil răspunderii penale pentru infracțiunea de falsificarea probelor, în strictă conformitate cu condiționalitățile normative ale art.374 Cod penal al Republicii Italia.

În lumina reperelor enunţate mai sus, şi în special a variantelor tipice de incriminare a infracțiuni de falsificarea probelor în Legea penală a Turciei și a Italiei în co-raport cu prevederile art.310 Cod penal al Republicii Moldova, reiterăm că, modalitatea normativă precitată care-și găsește locul de dislocare juridică în Capitolul cu titulatura Infracțiuni contra justiției din Partea specială a Codului penal al Republicii Moldova, merită a fi supus unor completări și ajustări de rigoare, pentru a fi posibil de a atrage la răspundere penală subiecții de drept care săvârșesc infracțiunea de falsificarea probelor prin diverse forme și acțiuni ilicite.

O poziție normativă elocventă a incriminării infracțiunii de falsificarea probelor, poate fi regăsită cu uşurință și în cea mai vestică țară din Europa continentală - Republica Portugheză.

Legiuitorul portughez (Adunarea Republicii Portugalia) a nominalizat expres varianta normativă a infracțiuni precitate în limitele legale ale Capitolului II cu denumirea marginală Infracțiuni contra falsificării.

Așadar, art.256 din Codul penal al Republicii Portugalia cu titlul generic Falsificarea documentului, prevede expres că, orice persoană care cu intenţia de a provoca daune altei persoane sau statului, în vederea obținerii pentru sine sau pentru o altă persoană a unui beneficiu ilicit sau pentru a pregăti, facilita, executa sau ascunde $o$ altă infracțiune:

a) creează ori întocmește un document fals sau oricare dintre componentele vizate ce-l cuprinde;

b) forjează ori modifică un document sau oricare dintre componentele care îl integrează;

c) admite unele abuzuri de la semnătura altei persoane pentru falsificarea sau contrafacerea unui document;

d) include date false într-un document sau în oricare dintre componentele sale un fapt relevant din punct de vedere juridic;

e) utilizează un document falsificat;

f) sau prin orice mijloace, acordă sau deține un document falsificat - constituie o infracțiune din categoria faptelor ilicite de falsificarea probelor. Pedeapsa pentru o asemenea faptă - este una de tipul închisorii pe un termen de cel mult trei ani de zile calendaristici, în conformitate cu prevederile art.256 alin.(1) din Codul penal al Republicii Portugalia.

Totodată, dacă făptuitorul care încearcă să realizeze unele din acţiunile enumerate mai sus, însă din cauze independente nu-și atinge scopul - la fel este pasibil răspunderii penale (tentativa de infracțiune), potrivit sistemului normativ prevăzut la art.256 alin.(2) din Codul penal al Republicii Portugalia.

Este important de menționat că, în condițiile în care făptuitorul realizează unele din acțiunile precitate de la art.256 alin.(1) din Codul penal al Republicii Portugalia, însă aceste acțiuni se referă la un document autentificat sau cu forță egală, la un testament închis, la o comandă monetară poștală, cambie, cec ori la un alt document comercial transferabil prin aprobare sau la orice alt certificat de credit - la fel este pasibil răspunderi penale pentru comiterea infracțiunii de falsificarea probelor. $\mathrm{O}$ asemenea faptă, se sancționează cu pedeapsă de tipul închisori pe un termen de la şase luni până la cinci ani, 
potrivit condiţionalităţilor enunțate la art.256 alin.(3) din Codul penal al Republicii Portugalia.

Prin urmare, dacă acțiunile enunțate mai sus de la art.256 alin.(1) și alin.(3) din Codul penal al Republicii Portugalia sunt săvârșite de către un ofițer de poliție în procesul îndeplinirii atribuțiilor sale funcționale - acesta la fel va fi atras la răspundere penală. Sancţiunea pentru o asemenea faptă este una de tipul închisorii pe un termen de la unu până la cinci ani de zile calendaristici, în conformitate cu prevederile art.256 alin.(4) din Codul penal al Republicii Portugalia [4, art.256].

În condițiile descrise, este notabil de specificat că, legiuitorul portughez în limitele Legii penale a prevăzut expres și explicaţia normativă a unor termeni juridici care formează acțiunea de realizare a infracțiuni de falsificarea probelor.

Așadar, din art.255 al Codului penal din Republica Portugalia cu titulatura Definiții legale referitor la falsificare, reiese o abordare explicită a unor termeni relevanți.

Prin urmare, în temeiul art.255 Cod penal al Republicii Portugalia, la categoria conceptului de Document - se subînțelege declarația făcută în scris ori înregistrată pe un disc, casetă înregistrată sau orice alt mijloc tehnic, inteligibil pentru generalitatea oamenilor sau pentru un anumit cerc de oameni, ca, permițând recunoașterea emitentului adecvat ce dovedește un fapt relevant din punct de vedere juridic, dacă un astfel de scop este acordat la momentul emiterii sale, fie ulterior; precum şi semnul făcut material, dat sau plasat într-un lucru care să dovedească un fapt relevant din punct de vedere juridic și care permite recunoașterea de către generalitatea oamenilor sau de către un cerc specific de oameni a scopului său și dovezile care rezultă din acestea.

Adnotare tehnică - înseamnă adnotarea unei valori, a greutăţii sau a unei măsuri, a unui stadiu ori a unui eveniment, făcută cu ajutorul unui aparat tehnic care, total sau parțial, funcționează automat, care permite recunoașterea de către generalitatea oamenilor ori de către un anumit cerc de oameni cu rezultatele sale și are ca scop să dovedească un fapt relevant din punct de vedere juridic, indiferent dacă un astfel de scop este acordat la momentul executării acestuia, sau fie ulterior.

Document de identificare sau de călătorie - este cardul cetățeanului, cartea de identitate, paşaportul, viza, autorizația de ședere sau titlul, permisul de conducere, buletinul de naștere, certificatul ori alte certificate sau declarații cărora legea le acordă forța pentru identificarea persoanelor sau a situației lor profesionale ori alte circumstanțe, din care poate rezulta drepturi sau avantaje, şi anume în ceea ce privește mijloacele de trai, trimitere, detașare, călătorie, asistență, sănătate ori câștiguri de viață sau îmbunătățirea nivelului său personal.

Bani - sunt mijloace bănești de hârtie, care conțin

${ }^{2}$ Parlamentul Regatului Unit al Marii Britanii și Irlandei de Nord este instituția legislativă supremă a Regatului Unit al Marii Britanii şi al Irlandei de Nord, a bancnote și monede metalice, care este legal prevăzut în Portugalia sau în străinătate [4, art.255].

În repertoriul mențiunilor precitate, facem o analiză comparativă meritorie care constă în faptul că, legiuitorul portughez în co-raport cu cel moldav, a fost unul foarte tălmăcit la capitolul incriminării infracțiunii de falsificarea probelor.

Adunarea Republicii Portugalia a aprobat dislocarea expresă a infracțiuni supuse cercetării în limitele modalității normative din cadrul art.256 Cod penal al Republicii Portugalia. Această normă juridică, cuprinde în conţinutul său, o serie întreagă de acțiuni şi forme agravante care sancționează acțiunile ilicite de falsificarea probelor.

Simultan cu aceasta, legiuitorul portughez nu a rămas succint nici la capitolul definirii termenilor juridici, care fac obiectul infracțiunii de falsificarea probelor. Astfel, această cale de incriminare directă în Legea penală a unor definiții, denotă limitele normative exacte de încadrare juridică a acțiunilor ilegale comise în realitatea obiectivă, care formează elementele componente ale infracțiuni de falsificarea probelor.

În continuitatea idei de cercetare iniţiată în prezentul demers științific, este de menționat că, Regatul Unit al Marii Britanii și Irlandei de Nord fiind o țară suverană din Europa occidentală, situată în largul coastelor de nord-vest ale continentului European - la fel își are propriile sale norme de conduită. Dreptul Uniunii Europene este transpus în mod activ în sistemele juridice ale Regatului Unit în cadrul puterii legale a parlamentului britanic, care are drept scop îndeplinirea obligațiilor sale de tratat UE.

Modalităţile normative incriminate în Codul penal al Regatului Unit al Marii Britanii şi Irlandei de Nord (Actul privind justiția penală din Regatul Unit) la capitolul infracțiuni de falsificarea probelor, sunt diferite de cele enumerate în alte state, în conținutul precitat.

Prin urmare, Parlamentul Regatului Unit ${ }^{2}$, a instituit expres dispozițiile normative a acțiunilor veridice și admisibile care formează complexul infracțiuni de falsificarea probelor, fără a fi prevăzute elementele sistemului sancționator care ar contribui la aplicarea răspunderii penale pentru falsificarea dovezilor.

În capitolul I cu denumirea generică Dovezi ale caracterului rău din limitele legislative ale pârții a XI-a cu denumirea marginală Dovezi a Codului penal al Regatului Unit al Marii Britanii și Irlandei de Nord, este dislocat art.101 cu titulatura Caracterul rău al inculpatului, ce specifică direct care sunt acțiunile legitime de administrare a probelor în cadrul unui proces penal.

Astfel, corespunzător art.101 al Actului privind justiția penală din Regatul Unit, în procedurile penale, probele privind caracterul rău al inculpatului sunt

Dependențelor Coroanei Britanice și a Teritoriile britanice de pretutindeni. 
admisibile dacă:

a) toate părțile la procedură sunt de acord cu probele admisibile;

b) probele sunt aduse de inculpat însuși sau sunt oferite ca răspuns la o întrebare adresată de acesta în cadrul unei examinări încrucișate (confruntare) și destinate să o provoace;

c) este o dovadă explicativă importantă;

d) este relevant pentru o chestiune importantă în discuție între inculpat și urmărirea penală;

e) are o valoare aprobativă substanțială în legătură cu o problemă importantă în discuție între pârât și coinculpat;

f) este o dovadă pentru a corecta o impresie falsă dată de pârât;

g) inculpatul a atacat caracterul altei persoane [5, art.101].

Consecvent cu aceasta, este de notat că, în Codul penal al Regatului Unit al Marii Britanii și Irlandei de Nord se regăsește și o altă formulare normativă care formează obiectul unei infracțiuni de falsificarea probelor.

Art.105 cu denumirea legislativă Dovadă pentru corectarea unei impresii false, asemenea ca și mențiunile prenotate instituie expres modalităţile de admitere a probelor în cadrul proceselor judiciare.

Așadar, în cazul în care, în procedurile penale dovezile administrate reprezintă o probă pentru a corecta o impresie falsă dată de pârât:

1. inculpatul dă o impresie falsă dacă este responsabil de formularea unei afirmații exprese sau implicite, care este apt să dea instanței sau juriului o impresie falsă sau înșelătoare despre inculpat;

2. probele pentru a corecta o astfel de impresie sunt dovezi care au valoare aprobativă în corectarea acesteia - potrivit art.105 alin.(1) Cod penal al Regatului Unit al Marii Britanii și Irlandei de Nord.

Un inculpat este considerat răspunzător pentru formularea unei afirmații dacă:

a) afirmația este făcută de pârât în cadrul procedurii judiciare (indiferent dacă este sau nu dovedit de acesta);

b) afirmația a fost făcută de către pârât:

- după ce a fost pus sub ,,semnul atenției”, înainte de acuzație, despre infracțiunea cu care este acuzat;

- după ce a fost acuzat de infracțiune sau a fost informat oficial că ar putea fi urmărit penal pentru aceasta, iar dovada acestei afirmații este prezentată în procedură,

c) afirmația este făcută de un martor chemat de inculpat;

d) afirmația este făcută de orice martor în cadrul unei examinări încrucișate (confruntare), ca răspuns la o întrebare adresată de pârât, care are intenția să o provoace sau este posibil să o facă;

e) afirmația a fost făcută de orice persoană în afara instanței, iar inculpatul adaugă probe în cadrul procedurii - în condiţionalităţile art.105 alin.(2) Cod penal al Regatului Unit al Marii Britanii și Irlandei de Nord.
La fel, un inculpat care, ar fi tratat ca fiind responsabil pentru prezentarea dovezilor nu va fi atras la răspundere dacă, își recunoaște vinovăția sau se dezonorează de îndeplinirea acestei acțiuni ilicite - în conformitate cu art.105 alin.(3) Cod penal al Regatului Unit al Marii Britanii și Irlandei de Nord.

În cazul în care, instanța de judecată constată că un inculpat, prin comportamentul său în cadrul procesului judiciar, încearcă să ofere (prezinte) instanței sau juriului o impresie despre el însuși fals sau înșelător, instanța îl poate considera pe inculpat ca fiind responsabil pentru prezentarea dovezilor false - potrivit prevederilor art.105 alin.(2) Cod penal al Regatului Unit al Marii Britanii şi Irlandei de Nord [5, art.105].

În condițiile enunțate mai sus, notabil este faptul că, legiuitorul autohton a dislocat expres variantele tipice normative la art.310 Cod penal al Republicii Moldova a infracțiunii de falsificarea probelor, care conține în structura sa dispoziţia și evident forma sancționatorie care îi este aplicată făptuitorului pentru admiterea cu bună-știință în realitatea obiectivă a acțiunilor ilicite de falsificarea probelor. Pe când, într-o altă ordine structurală, Parlamentul Regatului Unit fiind un organ legislativ care-și desfășoară activitatea după cele patru sisteme legale, fiecare derivând dintr-o anumită zonă geografică și pentru o varietate de motive istorice: dreptul englez, dreptul scoțian, dreptul Irlandei de Nord și dreptul pur galez (Țara Galilor), a instituit acțiunile și formele care cad sub incidența conceptului de „falsificarea probelor” într-o modalitate distinctivă.

Prin urmare, în Codul penal al Regatului Unit al Marii Britanii și Irlandei de Nord, întâlnim doar variantele tipice normative care indică direct doar elementul dispozitiv al modalităţilor legislative a infracțiunii de falsificarea probelor, și anume acea modalitate care instituie caracterul legitim de admisibilitate a probelor într-un proces judiciar.

Concluzii. În prezentul demers științific, au fost descrise, analizate și comparate diverse modalități normative a infracțiunii de falsificarea probelor care își găsesc sediul legislativ de incriminare în unele Legii penale a statelor lumii. Însă, punctul forte care a stat la baza respectivului studiu, a fost identificarea, elucidarea și înaintarea unor propunerii esențiale în vederea completării și armonizării legislației naționale la capitolul atragerii la răspundere penală a tuturor formelor şi acțiunilor ilicite de falsificare a probelor care pot fi săvârșite în realitatea obiectivă.

Așadar, cu titlul generic de lege ferenda se înaintează instituirea art.310 11 din Codul penal al Republicii Moldova, cu denumirea marginală Prezentarea probelor false și structura normativă în ordinea care succede.

\section{Articolul 310 ${ }^{11}$. Prezentarea probelor false.}

Prezentarea probelor false de către un subiect de drept în cadrul unui proces civil, penal, contravențional și/sau administrativ în favoarea altei persoane cu sau fără ulterioara beneficiere a unor recompense se pedepsește cu amendă în mărime de la 500 la 750 unități 
convenționale sau cu muncă neremunerată în folosul comunității de la 100 la 150 de ore în ambele cazuri cu (sau fără) privarea de dreptul de a ocupa anumite funcții sau de a exercita o anumită activitate pe un termen de până la 2 ani.

\section{Referințe bibliografice:}

1) Codul penal al Republicii Moldova nr.985-XV din 18 aprilie 2002 // Republicat în Monitorul Oficial al Republicii Moldova în 2009. Poate fi accesat la link-ul: lex.justice.md/md/331268/, (vizualizat 12.10.2020);

2) Codul penal al Republicii Turcia din 01.06.2005, cu ultimele modificări, completări şi ajustări din 15.02.2016. Poate fi accesat la link-ul: https://www.wipo.int/edocs/lexdocs/laws/en/tr/tr171en.pdf, (vizualizat la 26.10.2020);

3) Codul penal al Republicii Italiene aprobat prin Decretul Regal nr.1398 din 19.10.1930, cu ultimele modificări, completări și ajustări din 20.12.2012. Poate fi accesat la link-ul: https://www.altalex.com/documents/codicialtalex/2014/10/30/codice-penale, (vizualizat la 27.10.2020);

4) Codul penal al Republicii Portugalia nr.59 din 04.09.2007, cu ultimele modificări, completări și ajustări din 01.01.2019. Poate fi accesat la link-ul: https://www.icmec.org/wp-content/uploads/2019/02/ICMEC-Portugal-NationalLegislation.pdf, (vizualizat la 28.10.2020);

5) Codul penal al Regatului Unit al Marii Britanii și Irlandei de Nord (Actul privind justiția penală din Regatul Unit), adoptat prin Consimțământul Regal din 20.11.2003, cu ultimele modificări, completări și ajustări din 08.05.2020. Poate fi accesat la link-ul: http://www.legislation.gov.uk/ukpga/2003/44/contents, (vizualizat la 30.10.2020). 